Research Paper

\title{
Synergistic Efiects of Honey and Propolis toward Drug Multi-Resistant Staphylococcus Aureus, Escherichia Coli and Candida Albicans Isolates in Single and Polymicrobial Cultures
}

\author{
Noori AL-Waili ${ }^{凶}$, Ahmad Al-Ghamdi, Mohammad Javed Ansari, Y. Al-Attal, Khelod Salom \\ Department of Plant Protection, College of Food and Agricultural Sciences, King Saud University- Riyadh, 11543, KSA; Waili \\ Foundation for Science, Queens, NY 11418, NY, USA.
}

Corresponding author: Dr. Noori AL-Waili, email: Drnoori6@yahoo.com.

(c) Ivyspring International Publisher. This is an open-access article distributed under the terms of the Creative Commons License (http://creativecommons.org/ licenses/by-nc-nd/3.0/). Reproduction is permitted for personal, noncommercial use, provided that the article is in whole, unmodified, and properly cited.

Received: 2012.06.10; Accepted: 2012.08.19; Published: 2012.10.26

\begin{abstract}
Background: Propolis and honey are natural bee products with wide range of biological and medicinal properties. The study investigated antimicrobial activity of ethyl alcohol extraction of propolis collected from Saudi Arabia (EEPS) and from Egypt (EEPE), and their synergistic effect when used with honey. Single and polymicrobial cultures of antibiotic resistant human pathogens were tested.

Material and methods; Staphylococcus aureus (S. aureus),), Escherichia coli (E. coli) and Candida albicans (C.albicans) were cultured in $10-100 \%(\mathrm{v} / \mathrm{v})$ honey diluted in broth, or $0.08-1.0 \%$ (weight/volume) EEPS and EEPE diluted in broth. Four types of polymicrobial cultures were prepared by culturing the isolates with each other in broth (control) and broth containing various concentrations of honey or propolis. Microbial growth was assessed on solid plate media after $24 \mathrm{~h}$ incubation.

Results; EEPS and EEPE inhibited antibiotic resistant E.coli, and S.aureus, and C.albicans in single and polymicrobial cultures. S.aureus became more susceptible when it was cultured with E.coli or C.albicans or when all cultured together. C.albicans became more susceptible when it was cultured with S.aureus or with E.coli and S. aureus together. The presence of ethyl alcohol or honey potentiated antimicrobial effect of propolis toward entire microbes tested in single or polymicrobial cultures. EEPS had lower MIC toward E.coli and C.albicans than EEPE. When propolis was mixed with honey, EEPS showed lower MIC than EEPE. In addition, honey showed lower MIC toward entire microbes when mixed with EEPS than when it was mixed with EEPE.

Conclusion; I) propolis prevents the growth of the microorganisms in single and mixed microbial cultures, and has synergistic effect when used with honey or ethyl alcohol, 2) the antimicrobial property of propolis varies with geographical origin, and 3) this study will pave the way to isolate active ingredients from honey and propolis to be further tested individually or in combination against human resistant infections.
\end{abstract}

Key words: Honey, Propolis, bacteria, Fungi, synergism.

\section{Introduction}

Propolis is a resinous natural substance produced by honeybees from plant exudates, beeswax, and bee secretions. Propolis is composed of $50 \%$ resin,
$30 \%$ wax, $10 \%$ essential and aromatic oils, $5 \%$ pollen, and $5 \%$ other substances. However, the composition varies according to the geographical and plant 
sources, and the collection season. The main function of propolis in honey bee hives is to control temperature, light, and humidity. Furthermore, it protects hives from pathogens and some colony invaders. Propolis has wide range of biological activities which include antimicrobial, antioxidant, anti-inflammatory, anaesthetic and anticancer properties.

The antimicrobial activities of propolis toward various pathogens have been widely investigated. Propolis poses bacteriostatic activity against different bacteria, and in high concentration it has a bactericidal activity $(1,2)$. However, few studies have been published regarding its effects against multi-resistant pathogens. It was found that propolis can inhibit fluconazole-resistant Candida glabrata (3). Other studies showed that ethanol extract of propolis inhibits drug multi-resistant bacteria, MRSA, Enterococcus spp. and Pseudomonas aeruginosa (4-8). A study on the effect of ethanolic extract of propolis (collected from Turkey) against 39 microorganisms (14 resistant or drug multi-resistant to antibiotics) showed significant antimicrobial activities against Gram-positive bacteria and yeasts, while Gram-negative bacteria were less susceptible (9).

Synergism between propolis and antibacterial agents has been observed (10-12). In this regard, it was found that there is synergism between propolis and antimicrobial drugs against $S$. aureus especially those agents that interfere on bacterial protein synthesis (12). Data showed that the combinations of propolis extract plus clarithromycin improved inhibition of $H$. pylori with synergistic or additive activity (13). A study investigating the possible synergism between propolis (collected in Brazil and Bulgaria) and antibiotics acting on the ribosome (chloramphenicol, tetracycline and neomycin) against Salmonella showed that Bulgarian propolis had antibacterial action, as well as a synergistic effect with antibiotics acting on the ribosome (14).

Regarding polymicrobial culture, so far there is no study investigating the effect of propolis on the growth of multiple pathogens cultured together on the same media. In addition, to our knowledge there is no study investigating the synergism between propolis and honey.

Other researchers and the authors have demonstrated that honey has a potent antimicrobial activity (15-20). In addition, we have found that honey has considerable antimicrobial activity against fungi and bacteria when cultured together (21). Honey was mentioned in the Holy Quran 1400 years ago (And thy LORD taught the bee to build its cells in hills, on trees and in men's habitations, then to eat of all the produce of the earth and find with skill the spacious paths of its LORD, there issues from within their bodies a drink of varying colors, wherein is healing for men, verily in this is a sign for those who give thought). It is also mentioned in the Talmud. Hippocrates and Celsus used honey for wounds and ulcers. Prophet Mohammed recommended honey for the treatment of diarrhea.

The objectives of the present work are: 1) the investigation of the antimicrobial activity of propolis collected from King Saudi Arabia against drug resistant bacteria and fungi and comparison with the antimicrobial activities of propolis collected from Egypt, 2) the study of the antimicrobial effect of propolis against antibiotic resistant polymicrobial cultures, and 3) the study of synergism between honey and propolis toward single microbial and polymicrobial cultures. Therefore, this is the first study investigating the synergism between propolis and honey and their effects on polymicrobial cultures.

\section{Materials and Methods}

\section{Propolis preparation}

Propolis was crushed after freezing with liquid nitrogen to make a powder. The latter was added to $70 \%$ ethyl alcohol and kept in a beaker covered with aluminum foil for one week at room temperature. The alcohol was evaporated and propolis was weighed and subjected to one of two methods of propolis concentration preparation;

- Propolis in ethyl alcohol; The powder was dissolved in $70 \%$ ethyl alcohol to make propolis concentration $4.5 \%$ (weight/volume) and then various concentrations were made after dilution with nutrient agar (0.05 to $1.0 \%$ ).

- Propolis in broth; the powder was dissolved in $70 \%$ ethyl alcohol and then kept in bathwater at $37^{\circ} \mathrm{C}$ in order to evaporate ethyl alcohol. The powder was weighted and dissolved in nutrient broth to make a concentration of $4.5 \%$ (weight/volume) and various concentrations were made after dilution with nutrient agar $(0.05$ to $1.0 \%)$.

In the first method, a minute amount of ethyl alcohol remained in the various concentrations of propolis, while in the second method ethyl alcohol was evaporated before dilution in the nutrient broth, so that pure propolis/nutrient broth was obtained.

\section{Honey sampling}

Sumra honey (Acacai Tortilis) was collected from Tahama, King Saudi Arabia. It was dark amber in color and it showed no sign of granulation or fer- 
mentation. Analysis of honey was done and revealed TDS 84.6, moisture 15.1, $\mathrm{pH} 3.66$, glucose $32.3 \%$, fructose $35.4 \%$, sucrose $3 \%$, Na $488 \mathrm{mg} / 100 \mathrm{~g}$ of honey, $\mathrm{Mg} 2.1 \mathrm{mg} / 100 \mathrm{~g}$ of honey, $\mathrm{K} 499 \mathrm{mg} / 100$ gram honey, Ca $16.2 \mathrm{mg} / 100 \mathrm{~g}$ of honey, Mn $0.10 \mathrm{mg} / 100 \mathrm{~g}$ of honey, $\mathrm{Cu} 0.172 \mathrm{mg} / 100 \mathrm{~g}$ of honey and $\mathrm{Zn} 0.283$ $\mathrm{mg} / 100 \mathrm{~g}$ of honey. The volume of honey necessary to achieve the required concentrations $(10-100 \%, \mathrm{v} / \mathrm{v})$ was aseptically added into sterile test tubes and nutrient broth was added to obtain the required honey concentration. Honey broth solutions were mixed by stirring with vortex.

\section{Preparation of Human pathogen cultures}

Fresh cultures of human pathogens, which included S.aurues, E. coli and C. albicans, were obtained from the Microbiology Department, Bee Research Unit, King Saud University, Riyadh. The isolates were identified by the standard bacteriological techniques. The Kirby-Bauer method was used to test antibiotic sensitivity. Using a 10 microliter standard loop, a colony of each isolate was picked from the plate and transferred into $10 \mathrm{ml}$ nutrient broth, and this broth culture was used after $24 \mathrm{~h}$ incubation in $37^{\circ} \mathrm{C}$. Bacterial growth was assessed visually on solid media as: 0 colonies $=$ no growth, 1-5 colonies=little growth, 6-20 colonies =mild growth, 21-50 colonies=moderate growth, $>50$ and uncounted colonies=heavy growth and uncounted colonies+ full streak growth= very heavy growth. The experiment was performed in duplicate for each culture to verify the results. The cultural media and materials were ready made and supplied by the King Saud University store department.

\section{Antimicrobial Effects of honey on single cul- tures of human pathogens}

In order to study the antimicrobial activity of the selected honey on the pathogenic isolates and to measure MIC the broth macro-dilution method was used. Specimen of each microorganism was taken from pure culture grown in $10 \mathrm{ml}$ nutrient broth as described above. These specimens were cultured in broth containing different concentrations of honey by using a standard loop $(10 \mu \mathrm{l})$. The cultures were incubated at $37^{\circ} \mathrm{C}$ for $24 \mathrm{~h}$. Then after a loopful $(10 \mu \mathrm{l})$ of the cultures of each of the specimens of microorganisms was streaked onto agar plates. The streaked plates were incubated aerobically at $37^{\circ} \mathrm{C}$ and inspected after $24 \mathrm{~h}$ to measure MIC.

\section{Antimicrobial Effect of propolis on single cul- tures of human pathogens}

In order to study the antimicrobial activity of the propolis from Saudi Arabia and from Egypt on the pathogenic isolates specimen of each pathogen was cultured in broth containing different concentrations of EEPS or EEPE to measure MIC. After incubation at $37{ }^{\circ} \mathrm{C}$ for $24 \mathrm{~h}$, a loopful of the cultures of each of the specimen microorganisms was streaked onto agar plates, incubated aerobically at $37^{\circ} \mathrm{C}$, and inspected after $24 \mathrm{~h}$ for microbial growth.

\section{Antimicrobial Effect of honey and propolis on polymicrobial culture}

Four types of mixed microbial cultures were prepared: mixture 1 contained S. aureus and S. E.coli; mixture 2 contained $S$. aureus and C. albicans; mixture 3 contained E.coli and C. albicans; and mixture 4 contained all three isolates. A loopful $(10 \mu l)$ of fresh culture of each isolate was used for cultivation. Each mixture was cultured into broth (control) and into tubes containing various honey, EEPS and EEPE concentrations in broth. These cultures were incubated at $37^{\circ} \mathrm{C}$ for $24 \mathrm{~h}$. Then a loopful of the cultures of each of the specimen of the mixture was streaked onto appropriate solid agar plates to assess the viability of the isolates. Solid media included a mannitol salt agar for S. aureus, a MacConkey agar medial for E. coli, and Sabouraud media for $C$. albicans. The streaked plates were incubated aerobically at $37^{\circ} \mathrm{C}$ and inspected after $24 \mathrm{~h}$.

\section{Antimicrobial Synergism of honey and propo- lis toward human pathogens}

After determination of MIC of honey and propolis, various concentrations of honey and propolis below their MIC were prepared. Mixtures of honey and propolis were prepared by mixing various concentrations of honey with various concentrations of EEPS or EEPE (below their MIC). These mixtures were tested against the same pathogens as described above to identify whether there was synergism between honey and propolis. Synergism was identified when the MIC of honey or propolis in combination was lower than the MIC of honey or propolis alone.

\section{Effects of ethyl alcohol on microbial growth}

This experiment was designed to test if ethyl alcohol used to dissolve propolis before various concentrations were prepared in nutrient broth would pose anti-microbial effect. Specimen of each pathogen was cultured in broth containing different concentrations of ethyl alcohol similar to those obtained after re-dissolving propolis and dilution to measure MIC toward single and polymicrobial cultures of the isolates. After incubation at $37^{\circ} \mathrm{C}$ for $24 \mathrm{~h}$, a loopful of the cultures of each of the specimen microorganisms was streaked onto agar plates, incubated aerobically 
at $37^{\circ} \mathrm{C}$, and inspected after $24 \mathrm{~h}$ for microbial growth. Four types of mixed microbial cultures were prepared as above. Each mixture was cultured onto broth (control) and onto tubes containing various ethyl alcohol concentrations in broth. These cultures were incubated at $37^{\circ} \mathrm{C}$ for $24 \mathrm{~h}$. Then a loopful of the cultures of each of the specimen of the mixture was streaked onto appropriate solid agar plates to assess the viability of the isolates. The streaked plates were incubated aerobically at $37^{\circ} \mathrm{C}$ and inspected after $24 \mathrm{~h}$.

\section{Results}

Antimicrobial resistance testing showed that S.aureus was resistant to cefuroxime, amoxicillin, ampicillin, and chloramphenicol while E.coli was resistant to linezolid, vancomycin, erythromycin, cefuroxime, ampicillin, and kanamycin.

Regarding the effect of ethyl alcohol prepared to dissolve propolis on the pathogens, the result showed that similar concentrations of ethyl alcohol in nutrient broth did not show anti-microbial effects. EEPS inhibited E.coli, S.aureus and C.albicans in single microbial culture and in polymicrobial culture (Table 1). S.aureus became more susceptible to EEPS when cultured with E.coli or C.albicans or when all cultured together. C.albicans became more susceptible to EEPS when it was cultured with S.aureus or with E.coli and $S$. aureus together. This showed that polymicrobial culture increases microbial susceptibility toward propolis collected in Saudi Arabia. EPPS, after vaporization of ethyl alcohol showed similar inhibitory properties toward single microbial culture of the isolates tested (Table 1,2). Regarding polymicrobial cultures, the presence of ethyl alcohol in various concentrations of popolis prepared in nutrient broth decreased MIC of EEPS towards most of the cultures (Table 1,2). MIC of both EEPS and honey (when mixed together) was lower than their MIC (when tested individually) toward entire microbes tested in single or polymicrobial cultures (Tables 3,4 ).

EEPE inhibited all pathogens in single or polymicrobial cultures (Table 5). E.coli and S.aureus were more susceptible to EEPE when they were cultured with C.albicans. When C.albicans and E.coli cultures combined; E.coli became more susceptible to $E E P E$. This showed that polymicrobial culture increases microbial susceptibility toward EEPS. MIC of EEPE and honey toward all the microorganisms was lower, when EEPE and honey combined, than MIC of honey or EEPE alone (Table 6). This might reveal synergism between them.

EEPS had lower MIC toward E.coli and C.albicans than EEPE. When propolis mixed with honey, EEPS showed lower MIC than EEPE; this means that EEPS exhibited stronger synergism than EEPE. In addition, honey showed lower MIC toward entire microbes when mixed with EEPS than when it was mixed with EEPE (Table 7).

Table I. MIC of propolis (collected in Saudi Arabia) dissolved in ethyl alcohol toward single or polymicrobial cultures. VH: very heavy growth;*** not tested.

\begin{tabular}{|c|c|c|c|c|c|c|}
\hline \multirow[t]{2}{*}{ Pathogens } & \multirow{2}{*}{$\begin{array}{l}\text { Control culture } \\
\text { growth }\end{array}$} & \multirow{2}{*}{$\begin{array}{l}\text { MIC when propolis dis- } \\
\text { solved in ethyl alcohol } \\
\text { used in single culture }\end{array}$} & \multicolumn{4}{|c|}{ MIC when propolis dissolved in ethyl alcohol used in polymicrobial cultures } \\
\hline & & & E.coli + C. albicans & E.coli + S. aureus & $\begin{array}{l}\text { C. albicans }+S \text {. } \\
\text { aureus }\end{array}$ & $\begin{array}{l}\text { E.coli }+ \text { C. albicans }+S . \\
\text { aureus }\end{array}$ \\
\hline E.coli & $\mathrm{VH}$ & 0.15 & 0.15 & 0.15 & *** & 0.15 \\
\hline S.aureus & $\mathrm{VH}$ & 0.15 & $* * * *$ & 0.10 & 0.10 & 0.10 \\
\hline C.albicans & $\mathrm{VH}$ & 0.20 & 0.20 & $* * *$ & 0.18 & 0.15 \\
\hline
\end{tabular}

Table 2. MIC of propolis (collected in Saudi Arabia) dissolved in broth toward single or polymicrobial cultures. VH: very heavy growth, *** not tested.

\begin{tabular}{|c|c|c|c|c|c|c|}
\hline \multirow[t]{2}{*}{ Pathogens } & \multirow{2}{*}{$\begin{array}{l}\text { Control cul- } \\
\text { ture growth }\end{array}$} & \multirow{2}{*}{$\begin{array}{l}\text { MIC when propolis dis- } \\
\text { solved in broth used in } \\
\text { single culture }\end{array}$} & \multicolumn{4}{|c|}{ MIC when propolis dissolved in broth used in polymicrobial cultures } \\
\hline & & & E.coli + C. albicans & E.coli + S. aureus & C. albicans + S. aureus & $\begin{array}{l}\text { E.coli }+ \text { C. albicans }+S \text {. } \\
\text { aureus }\end{array}$ \\
\hline E.coli & $\mathrm{VH}$ & 0.15 & 0.20 & 0.20 & $* * *$ & 0.20 \\
\hline S.aureus & $\mathrm{VH}$ & 0.15 & *** & 0.15 & 0.15 & 0.15 \\
\hline C.albicans & $\mathrm{VH}$ & 0.20 & 0.20 & $* * *$ & 0.20 & 0.20 \\
\hline
\end{tabular}


Table 3. MIC of honey and propolis (collected in Saudi Arabia) alone or combined with honey toward single microbial culture.

\begin{tabular}{lllll}
\hline Pathogens & \multicolumn{2}{l}{ MIC when honey or propolis was used } & \multicolumn{2}{l}{ MIC $(\%)$ when combination used } \\
\cline { 2 - 5 } & Honey & Propolis & Honey & Propolis \\
\hline E.coli & 30 & 0.15 & 15 & 0.08 \\
S.aureus & 30 & 0.15 & 15 & 0.08 \\
C.albicans & 30 & 0.20 & 15 & 0.10 \\
\hline
\end{tabular}

Table 4. MIC (\%) of honey and propolis (collected from Saudi Arabia) when combined together toward polymicrobial cultures, *** not tested.

\begin{tabular}{|c|c|c|c|c|c|c|c|c|c|c|}
\hline \multirow[t]{3}{*}{ Pathogens } & \multirow{2}{*}{\multicolumn{2}{|c|}{$\begin{array}{l}\text { MIC when honey or } \\
\text { propolis was used in } \\
\text { single microbial culture }\end{array}$}} & \multicolumn{8}{|c|}{ MIC (\%) when combination used in polymicrobial cultures } \\
\hline & & & \multicolumn{2}{|c|}{ E.coli + C. albicans } & \multicolumn{2}{|c|}{ E.coli + S. aureus } & \multicolumn{2}{|c|}{ C. albicans + S. aureus } & \multicolumn{2}{|c|}{ E.coli + C. albicans + S. aureus } \\
\hline & Honey & Propolis & Honey & Propolis & Honey & Propolis & Honey & Propolis & Honey & Propolis \\
\hline E.coli & 30 & 0.15 & 15 & 0.08 & 15 & 0.08 & $* * *$ & $* * *$ & 15 & 0.08 \\
\hline S.aureus & 30 & 0.15 & $* * *$ & $* * *$ & 10 & 0.08 & 10 & 0.08 & 10 & 0.05 \\
\hline C.albicans & 30 & 0.20 & 15 & 0.08 & $* * *$ & $* * *$ & 15 & 0.10 & 15 & 0.10 \\
\hline
\end{tabular}

Table 5. MIC (\%) of propolis (collected in Egypt) toward single or polymicrobial cultures. VH: very heavy growth, *** not tested.

\begin{tabular}{|c|c|c|c|c|c|c|}
\hline \multirow[t]{2}{*}{ Pathogens } & \multirow[t]{2}{*}{ Control } & \multirow{2}{*}{$\begin{array}{l}\text { MIC when propolis used } \\
\text { in single culture }\end{array}$} & \multicolumn{4}{|c|}{ MIC when propolis used in polymicrobial cultures } \\
\hline & & & E.coli + C. albicans & E.coli + S. aureus & $\begin{array}{l}\text { C. albicans + S. au- } \\
\text { reus }\end{array}$ & $\begin{array}{l}\text { E.coli + C. albicans + S. au- } \\
\text { reus }\end{array}$ \\
\hline E.coli & $\mathrm{VH}$ & 0.25 & 0.15 & 0.25 & $* * *$ & 0.25 \\
\hline S.aureus & $\mathrm{VH}$ & 0.15 & $* * *$ & 0.15 & 0.15 & 0.15 \\
\hline C.albicans & $\mathrm{VH}$ & 0.25 & 0.15 & $* * *$ & 0.25 & 0.25 \\
\hline
\end{tabular}

Table 6. MIC of honey and propolis (collected in Egypt) alone or combined toward single microbial culture.

\begin{tabular}{lllll}
\hline Pathogens & MIC when honey used & MIC when propolis used & \multicolumn{2}{c}{ MIC when combination used } \\
\cline { 3 - 5 } & & & Honey & Propolis \\
\hline E.coli & 30 & 0.25 & 20 & 0.20 \\
S.aureus & 30 & 0.15 & 25 & 0.15 \\
C.albicans & 30 & 0.25 & 25 & 0.20 \\
\hline
\end{tabular}

Table 7. Comparison between MIC of propolis collected from Saudi Arabia or Egypt toward single microbial culture when used alone or combined with honey.

\begin{tabular}{lllll}
\hline Pathogens & \multicolumn{2}{l}{ MIC when propolis used } & \multicolumn{2}{l}{ MIC when propolis combined with honey } \\
\cline { 2 - 6 } & $\begin{array}{llll}\text { Propolis collected from } \\
\text { Saudi Arabia }\end{array}$ & $\begin{array}{l}\text { Propolis collected from } \\
\text { Egypt }\end{array}$ & $\begin{array}{l}\text { Propolis collected from Saudi } \\
\text { Arabia }\end{array}$ & $\begin{array}{l}\text { Propolis collected from } \\
\text { Egypt }\end{array}$ \\
\hline E.coli & 0.15 & 0.25 & 0.08 & 0.20 \\
S.aureus & 0.15 & 0.15 & 0.08 & 0.15 \\
C.albicans & 0.20 & 0.22 & 0.10 & 0.20 \\
\hline
\end{tabular}

\section{Discussion}

There published many studies suggesting that propolis exerts a strong anti-bacterial activity, in addition to antifungal, antiviral and antiprotozoal properties. However, so far no study has been conducted to investigate the antimicrobial influence of propolis on mixed microbial culture. This is the first study to report the effect of propolis on polymicrobial culture collected from human specimens. 
In one study by Stepanovic et al., the MIC of propolis against Gram-positive bacteria was $0.078 \%-1.25 \%$ and against yeasts was $0.16 \%-1.25 \%$, while against Gram-negative bacteria was less, $1.25 \%$ $5 \%$. Enterococcus faecalis was the most resistant Gram-positive bacterium, Salmonella spp. the most resistant Gram-negative bacteria, and $C$. albicans the most resistant yeast (11). In another study conducted in Portugal it was found that $C$. albicans was the most resistant and $S$. aureus the most sensitive to propolis collected from Portugal (30). In the present study MIC of propolis against Gram-positive $S$. aureus was $0.15 \%-0.25 \%$, against Gram-negative E.coli was $0.15 \%$ and against yeast C.albicans was $0.20 \%-0.22 \%$.

In the majority of the in vitro studies the antimicrobial activity of honey is measured by the size of the inhibition zone. For this purpose, the agar dilution assay technique or a disc impregnated in honey added to the agar inoculated with the microorganism was used. However, it was found that a disc impregnated with various concentrations of honey added to an agar plate became dry because of vaporization of fluid from the disc when the media were incubated at $73^{\circ} \mathrm{C}$ for 24 hours (22). Therefore, a series of various concentrations of honey or propolis in nutrient broth, in which the culture was grown, were used in the present study. By using this method, it was easy to find the MIC of honey or propolis that inhibited the growth of pathogens. The more potent the antimicrobial activity of honey or propolis is, the greater the dilution that inhibited the growth of microorganisms. Furthermore, many studies have diluted honey with distilled water to obtain various $\mathrm{v} / \mathrm{v}$ concentrations of honey (23-29). In the present study broth was used for dilution that closely matches wounds, which was a suitable medium for microbial growth.

The mechanism of propolis antimicrobial activity is complex and might be attributed to the synergistic activity between its various potent biological ingredients such as phenolics and flavonoids $(31,32)$. Basically, the antimicrobial properties of propolis are related to the synergistic effect of its various compounds (33).It was found that propolis affects the cytoplasmic membrane, and it inhibits bacterial motility, enzyme activity, cell division, and protein synthesis $(34,35)$. Galagin and caffeic acid derived from propolis are enzymatic inhibition agents in bacteria $(36,37)$. Propolis inhibits RNA-polymerase which can explain partially the synergism of propolis with drugs that act by inhibiting protein synthesis (35).

Many factors influence the antibacterial activity of propolis such as the propolis origin, bee species and extract preparation. The chemical composition of propolis demonstrates considerable geographic dif- ferences. Propolis from Bulgaria, Turkey, Greece and Algeria contains mainly flavonoids and esters of caffeic and ferulic acids (38). Flavonoids (pinocembrin and galangin) and esters of phenolic acids of European propolis have been associated with the antibacterial activity (39). Austrian propolis has a potent activity against C.albicans and German propolis was active against S.aureus and E. coli (40). In present study propolis collected from Saudi Arabia or Egypt has a potent antimicrobial activity against antibiotic resistant S. aureus and E.coli, and against C.albicans, tested in both single and polymicrobial cultures, and showed synergistic properties when they were mixed with honey. The effect of Brazilian propolis on H. pylori has been associated with lambdane-type diterpenes and some prenylated phenolic compounds (41). The effect of Bulgarian propolis on H. pylori was similar to that of Brazilian propolis fractions against oral anaerobic bacteria (MIC, 64-1024 $\mu \mathrm{g} \mathrm{ml-1)} \mathrm{(33).}$ Propolis collected from Saudi Arabia was more potent than that collected from Egyptian toward E.coli and C.albicans, and it exhibited stronger synergism when mixed with honey. Honey and propolis contains flavonoids and phenolic compounds and this might explain in part their synergistic effects. In addition, both honey and propolis stimulate antibody production $(42,43)$.

We have found for first time that honey collected from United Arab Emirates inhibits polymicrobial cultures as well as single microbial culture (21). In addition, polymicrobial culture of human pathogens increases their susceptibility to honey. Similar results were obtained in the present study; polymicrobial cultures increase the susceptibility of microorganisms to both propolis and honey. A great reduction was obtained in the growth of $S$. aureus when grown in the presence of E. coli. This reduction could not be explained by competition for nutrients because a higher grade of growth was obtained when $S$. aureus grew with other isolates (21). It was postulated that E. coli might secrete a Staphylococcus inhibitory factor that requires further investigation. Furthermore, studies have shown inhibition of $S$. aureus growth in mixed cultures with C. albicans (44). Pneudomonas aeruginosa produced substances that inhibited the growth of $S$. aureus (45). Significant suppression in the growth of $C$. pylori in the presence of Lactobacillus acidophilus was also observed (46).

The variations in antibacterial activity of honey can be related to the amount of hydrogen peroxide and the presence of additional antibacterial components derived from the nectar source. However, we have found that honey increased nitric oxide end products in various animals and humans' biological 
fluids and decreased prostaglandin concentration (47-49).

The minor reduction in the growth of isolates when cultured together might be a result of competition for a limited nutrient resource. However, such reduction might be due to unidentified soluble suppressor factors. Suppression of C. albicans by human salivary bacteria and by pure cultures of human oral strains of $S$. salivarius and S. mitior has been reported (50).

The spread of antibiotic resistance is a global public health problem and a challenging issue (51). The U.S. Centers for Disease Control and Prevention (CDC, 2000) has described antibiotic resistance as one of the world's most pressing health problems in the 21 st century $(52,53)$. It is well established that the number of bacteria resistant to antibiotics has increased, and many bacterial infections become resistant to the antibiotic treatments. The $\mathrm{WHO}$ has identified antibiotic resistance as "one of the three greatest threats to human health". Resistance includes agents used in the treatment of bacterial, fungal, parasitic, and viral infections. A wide range of biochemical and physiological mechanisms may be responsible for resistance. A recent database revealed the existence of more than 20,000 potential resistance genes (r genes) of nearly 400 different types (54). Long list of pathogens are becoming resistant to antibiotics, including Gram negative and Gram positive bacteria. It is clear that antibiotic resistance seems inevitable. Antibiotic resistance continues to rise, whereas development of new agents to counter it has slowed. The European Commission decided on an unprecedented approach to drive the search for novel antibiotics by integrating the pharmaceutical industry, the research capacities of universities and small companies supported by public funding along with pricing/reimbursement and regulatory bodies (55).

Our finding can add valuable knowledge in the efforts to develop new antimicrobial substances for challenging infections.

\section{Acknowledgement}

The authors are thankful to NPST program by King Saud University Riyadh, Project No. 11-AGR1748-02, for financial support.

\section{Competing Interests}

The authors have declared that no competing interest exists.

\section{References}

1. Drago L, Mombelli B, De Vecchi E, Fassina C, Tocalli L, Gismondo MR. In vitro antimicrobial activity of propolis dry extract. J Chemother 2000;12:390-395.
2. Sawaya A, Souza K, Marcucci M,Cunha I, Shimizu M. Analysis of the composition of Brazilian propolis extracts by chromatography and evaluation of their in vitro activity against gram-positive bacteria. Braz J Microbiol. 2004;35: 104-109

3. Shokri H, Khosravi AR, Yalfani R. Antifungal efficacy of propolis against fluconazole-resistant Candida glabrata isolates obtained from women with recurrent vulvovaginal candidiasis. Gynaecol Obstet 2011;114(2):158-159

4. Choudhari MK, Punekar S, Ranade RV, Paknikar K. Antimicrobial activity of stingless bee (Trigona sp.) propolis used in the folk medicine of Western Maharashtra. India J Ethnopharmacol. 2012; 141(1):363-367.

5. Vera N, Solorzano E, Ordoñez R, Maldonado L, Bedascarrasbure E, Isla M. Chemical composition of Argentinean propolis collected in extreme regions and its relation with antimicrobial and antioxidant activities. Nat Prod Commun. 2011; 6:823-827

6. Raghukumar R, Vali L, Watson D, Fearnley J, Seidel V. Antimethicillin-resistant Staphylococcus aureus (MRSA) activity of 'pacific propolis' and isolated prenylflavanones. Phytother Res 2010; 24(8):1181-1187.

7. Pepeljnjak S, Kosalec I. Galangin expresses bactericidal activity against multiple-resistant bacteria: MRSA, Enterococcus spp. and Pseudomonas aeruginosa. FEMS Microbiol Lett 2004 ;240(1):111-116.

8. Shub A, Kagramanova A, Voropaeva D, Kivman G. Effect of propolis on Staphylococcus aureus strains resistant to antibiotics. Antibiotiki 1981; 26:268-271.

9. Onlen Y, Duran N, Atik E, Savas L, Altug E, Yakan S, Aslantas O. Antibacterial activity of propolis against MRSA and synergism with topical mupirocin. J Altern Complement Med. 2007 Sep;13(7):713-718.

10. Krol W, Scheller S, Shani J, Pietsz G, Czuba Z. Synergistic effect of ethanolic extract of propolis and antibiotics on the growth of Staphylococcus aureus. Arzneimittelforschung 1993; 43: 607-609.

11. Stepanovic S, Antic N, Dakic I, Svabic-Vlahovic M. In vitro antimicrobial activity of propolis and synergism between propolis and antimicrobial drugs. Microbiol Res 2003; 158: 353-357.

12. FernandesJúnior A, Balestrin C, Betoni J, OrsiRde O, da Cunha Mde L, Montelli A. Propolis: anti-Staphylococcus aureus activity and synergism with antimicrobial drugs. Mem Inst Oswaldo Cruz. 2005 ;100:563-566.

13. Nostro A, Cellini L, Di Bartolomeo S, Cannatelli MA, Di Campli E, Procopio F, Grande R, Marzio L, Alonzo V. Effects of combining extracts (from propolis or Zingiberofficinale) with clarithromycin on Helicobacter pylori. Phytother Res 2006; 20(3):187-190.

14. Orsi RO, Fernandes A, Bankova V, Sforcin JM. The effects of Brazilian and Bulgarian propolis in vitro against Salmonella typhi and their synergism with antibiotics acting on the ribosome. Nat Prod Res 2012 ;26(5):430-437.

15. Bogdanov S, Jurendic T, Sieber R, Gallmann P. Honey for Nutrition and Health: A Review. J Amer Coll Nutrition, 2000; 27:677-689.

16. Al-Waili NS. Mixture of honey, beeswax and olive oil inhibits growth of Staphylococcus aureus and Candida albicans. Arch Med Res. 2005 ;36:10-13

17. Molan P. Why honey is effective as a medicine. 2 . The scientific explanation of its effects. Bee World 2001;82: 22-40.

18. Al-Waili NS, Salom K, Butler G, Al Ghamdi AA. Honey and microbial infections: a review supporting the use of honey for microbial control. J Med Food. 2011;14(10):1079-1096

19. Al-Waili NS, Akmal M, Al-Waili FS, Saloom KY, Ali A. The antimicrobial potential of honey from United Arab Emirates on some microbial isolates. Med Sci Monit. 2005 ;11(12):BR433-438

20. Gencay C, Kilicoglu S, Kismet K, Kilicoglu B, Erel S, Muratoglu S, Sunay AE, Erdemli E, Akkus M. Effect of honey on bacterial translocation and intestinal morphology in obstructive jaundice. World J Gastroenterol 2008;14:3410-3415

21. Al-Waili1 N, Al-Waili F, Mohammed Akmal, Amjed Ali, Salom K, Ahmad A. Al Ghamdi. Effects of natural honey on polymicrobial culture of various human pathogens. Arch Med Sci 2012;in press .

22. Al-Waili N. Investigating the Antimicrobial Activity of Natural Honey and Its Effects on the Pathogenic Bacterial Infections of Surgical Wounds and Conjunctiva. J Med Food. $2004 ; 7(2): 210-22$.

23. Allen K, Molan P. The sensitivity of mastitis-causing bacteria to the antibacterial activity of honey. NZ J Agricul Re 1997; 40: 537-40.

24. al Somal N, Coley KE, Molan PC, Hancock BM. Susceptibility of Helicobacter pylori to the antibacterial activity of manuka honey. J R Soc Med 1994; 87: 9-12.

25. Brady N, Molan P, Harfoot G. The sensitivity of dermatophytes to the antimicrobial activity of manuka honey and other honey. Phar Sci 1966; 2: 471-3. 
26. Cooper R, Molan P, Harding K. Antibacterial activity of honey against strains of Staphylococcus aureus from infected wounds. J R Soc Med 1999; 92: 283-5.

27. Cooper R, Molan P. The use of honey as an antiseptic in managing Pseudomonas infection. J Wound Care 1999; 8: 161-4.

28. Molan P, Allen K. The effect of gamma-irradiation on the antibacterial activity of honey. J Pharmacy Pharmacol 1996; 48: 1206-9.

29. Willix D, Molan P, Harfoot C. A comparison of the sensitivity of wound-infecting species of bacteria to the antibacterial activity of manuka honey and other honey. J Appl Bact 1992; 73: 388-94.

30. Silva J, Rodrigues S, Feás X, Estevinho L. Antimicrobial activity, phenolic profile and role in the inflammation of propolis. Food Chem Toxicol. 2012;50(5):1790-5

31. Krol W, Scheller S, Shani J, Pietsz G, Czuba Z. Synergistic effect of ethanolic extract of propolis and antibiotics on the growth of Staphylococcus aureus. Arzneimittel-forsch 1993; 43: 607-609.

32. Castaldo S, Capasso F. Propolis, an old remedy used in modern medicine. Fitoterapia 2002;73 (Suppl 1): S1-S6.

33. Santos, A, Bastos, M, Uzeda, M, Carvalho, A, Farias, L, Moreira, S, Braga, C. Antibacterial activity of Brazilian propolis and fractions against oral anaerobic bacteria. J Ethnopharmacol 2002; 80: 1-7.

34. Mirzoeva, O. K., Grishanin, R. N. \& Colder, P. C. Antimicrobial action of propolis and some of its components: the effect on growth, membrane potential and motility of bacteria. Microbiol Res 1997; 152: 239-246.

35. Takaisi-Kikuni NB, Schilcher H. Electron microscopy and microcalorimetric investigations of the possible mechanism of the antibacterial action of a defined propolis provenance. Planta Medica 1994; 60: 222-227

36. Koo H, Rosalen PL, Cury JA, Park YK, Bowen WH. Effects of compounds found in propolis on Streptococcus mutans growth and on glucosil transferase activity. Antimicrob Agents Chemother 2002; 46: 1302-1309.

37. Havsteem B. Flavonoids, a class of natural products of high pharmacology potency. Biochem Pharmacol 1983; 32: 1141-1148.

38. Velikova M, Bankova V, Sorkun K, Houcine S, Tsvetkova I, Kujumgiev A. Propolis from the Mediterranean region: chemical composition and antimicrobial activity. Z Naturforsch 2000; 55:790-793

39. Grange M, Davey W. Antibacterial properties of propolis (bee glue). J R Soc Med 1990; 83:159-160.

40. Hegazi A, Abd El Hady F, Abd Allah F. Chemical composition and antimicrobial activity of European propolis. Z Naturforsch 2000; 55:70-75

41. Banskota H, Tezuka Y, Adnyana I, Ishii E, Midorikawa K, Matsushige K, Kadota S. Hepatoprotective and anti-Helicobacter pylori activities of constituents from Brazilian propolis. Phytomedicine 2001; 8: 16-23.

42. Sforcin J, Orsi R, Bankova V. Effect of propolis, some isolated compounds and its source plant on antibody production. J Ethnopharmacol. 2005;98(3):301-305.

43. Al-Waili NS, Haq A. Effect of honey on antibody production against thymus-dependent and thymus-independent antigens in primary and secondary immune responses. J Med Food. $2004 ; 7(4): 491-494$

44. deRepentigny J, Lévesque R, Mathieu LG. Increase in the in vitro susceptibility of Staphylococcus aureus to antimicrobial agents in the presence of Candida albicans. Canad J Microbiol 1979; 25: 429-435.

45. Machan ZA, Pitt TL, White W. Interaction between Pseudomonas aeruginosa and Staphylococcus aureus: description of an anti-staphylococcal substance. J Med Microbiol 1991; 34: 213-217.

46. Bhatia S, Kochar N, Abraham P, Nair N, Mehta A. Lactobacillus acidophilus inhibits growth of Campylobacter pylori in vitro. J Clin Microbiol 1989; 27: 2328-2330.

47. Al-Waili N, Boni N. Natural honey lowers plasma prostaglandin concentrations in normal individuals. J Med Food 2003; 6: 129-133.

48. Al-Waili N, Boni N. Effects of honey on plasma, saliva and urinary nitric oxide production. J Med Food 2004; 7:377-380.

49. Al-Waili N. Effects of honey on the urinary total nitrite and prostaglandins concentration. Int Urol Nephrol 2005;37: 107-111.

50. Liljemark W, Gibbons RJ. Suppression of Candida albicans by human oral streptococci in genotobiotic mice. Infect Immun 1973; 8: 846-849.

51. Davies J, Davies D. Origins and Evolution of Antibiotic Resistance. Microbiol Mol Biol Rev 2010; 74(3): 417-433

52. Arias C, Murray B. Antibiotic-resistant bugs in the 21st century--a clinical super-challenge. N Engl J Med, 2009. 360: 439-43.

53. [Internet] CDC (Centers for Disease Control and Prevention). About Antimicrobial Resistance; A Brief Overview. http://www.cdc.gov/drugresistance/about.html.

54. Liu B, and Pop M. ARDB-Antibiotic Resistance Genes Database. Nucleic Acids Res. 2009. 37:D443-D447.
55. Theuretzbacher U. Accelerating resistance, inadequate antibacterial drug pipelines and international responses. Int J Antimicrob Agents. 2012 ;39(4):295-299. 